\title{
Rat Damage to Certain Vegetable Crops and Population Density of Arvicanthis niloticus (Desmart) with its Number of Active Burrows in Qalubia and Fayoum Governorates
}

\author{
Asran, A.A. and Y.M.A. Abd El Galil
}

Plant Protection Research Institute, ARC, Dokki, Giza, Egypt.

Received on: 9/8/2018

Accepted for publication on: $16 / 8 / 2018$

Abstract

Experiments were carried out during two successive years 2017 and 2018 in Qalubia (Kaha City-Tokh district) and Fayoum (Tamia district) Governorates. The aim was to study the correlation between the Field Nile Rat Arvicanthis niloticus (Desmart) population density and its active burrows per $100 \mathrm{~m}$., in and around the field both and its damage to each of tomato, green pepper (Rumi), peas and squash in February and March. Results proved that the Field Nile Rat, Arvicanthis niloticus (Desmart) damage percentage, population density and number of the active burrowsper $100 \mathrm{~m}$., in and around the field differs from crop to crop, from Governorate to Governorate and from month to anther during the repine stage. Also, the results obtained proved that there is a positive correlation between the rat damage percentages and each of population density of Rats and their active burrows per $100 \mathrm{~m}$., in and around the field. The highest percentage of damage, number of active burrows and rat population density was recorded on tomato crop during March in Fayoum Governorate. Meanwhile, the lowest figures for Arvicanthis niloticus (Desmart) damage, population density and number of active burrows per $100 \mathrm{~m}$., was recorded on green pepper (Rumi) during February in Qalubia Governorate.

Keywords: Damage assessment the Nile Field Rat Arvicanthis niloticus (Desmart), population density, active burrows, vegetables: (tomato, green pepper (Rumi), peas and squash)

\section{Introduction}

Rodents cause untold economic loss to farmers, food manufactures and processors, as well as causing damage to the structure and fabric of buildings. Undoubtedly, the economic loss due to rodents is enormous, particularly in the tropics (Meehan, 1984). The Worlds Health Organization (WHO) estimates that about 33 million tons of food is destroyed world wide each year. In the 1950's FAO experts estimated that $5 \%$ of food production was lost; enough to food production was lost; enough to food 130 million people at that time (Parkin, 1959). In Brazil, where beans are a major protein sources $5-10 \%$ lines are not unusual and in Argentine, material pastures which are used to grazehorses, sheep and cattle, can occasionally be destroyed (Woronecki,1973). Cassava, yams, taro, sweet potatoes and many other plants can be considered root crops. The true extent of its damage unknown, but losses of $5-10 \%$ are found in West Africa, and up to $15 \%$ in central Africa. Up to $30 \%$ damage is claimed for some root crops in the Pacific Islands and in Southern India rodents are major pests of guava (Lal, 
S.S. and Pillai, K.S., 1981). EL Deeb et al., (1985) found that tomatoes suffered the highest damage $(4.73 \%)$ followed by strawberry $(2.48 \%)$, squash $(1.41 \%)$ and peas $(0.43 \%)$ in some delta Governorates in Egypt. In general the losses to growing crops caused by rodents in temperate countries are significantly less than those in the tropics and subtropics and usually the species are some what deferent (Winygaarden, 1957). The national of some methods of estimating damage and losses has been reviewed, but the conclusion was that none of the methods is totally reliable (Jackson, 1977).

This manuscript aims to determine the most attractive vegetable crop to rats during its ripening stage. Also, to clear the kind of linkage between the rat damage to vegetable crops, with each of their population density and the number of active burrows per $100 \mathrm{~m}$ around and in the field.

\section{Materials and Methods}

The rats damage assessment was made only in the mature fruits of the studied vegetables, (tomatoes, green pepper Crouai), peas and squash. The technique of assessment was as follows: Forty sampling areas for each crop, two Feddan per each were taken by random in different locations in Qalubia, (Kaha city, Tokh district) and Fayoum (Tamiya district) Governorates. The rows in each two Feddan. Area were counted and divided by ten, the results and its duplicates were the numbers of sampling rows. For each sampling row, the damaged and undamaged fruits in thirty successive plants were counted and recorded. The tested plants in each row were located as follows: for each row, a random number from the random Table was chosen. This number, after deducting ten to out of it, represented the number of steps from the head of the field after which the thirty plants of the sample of the row a tested. The identification of rat damage was done as described by Asran et al., (1985). The percentage of damage was calculated as follows \%:

$\%$ damage $=\frac{\text { No. of damaged fruits }}{\text { Total No. of fruits }} \times 100$

The dominant rodent was determined in each crop by trapping for three successive nights. These traps were checked daily and the classified the rodents caught. The common rat was the Nile Field Rat, Arvicanthis niloticus (Desmart).

Regarding the population density of rats and their active burrows, twenty traps were prepared every two weeks in the site of each experiment for three successive nights. Thesetraps were checked daily and the entrapped rats were counted and identified. The population density percentage was calculated as follows:

population density $\%=\frac{\text { No. of entrapped rats }}{\text { No. of traps } \times \text { No. of nights }} \times 100$

The numbers of active burrows of the rats were counted in each 100 $\mathrm{m}$. in and around the chosen fields.

\section{Results and Discuccion}

Results in Tables one and two indicate that tomatoes was the most preferred to the Field Nile Rat Arvicanthis niloticus (Desmart) when compared to green pepper (Rumi), peas and squash under the field conditions of each of Qalubia and Fayoum Governorates at season of two successive years 2017/2018. The average percentages of rat damage to tomatoes were $0.58 \%$ and $0.66 \%$ dur- 
ing February and $0.69 \%$ and $0.78 \%$ during March, $0.33 \%$ and $0.37 \%$, $0.41 \%$ and $0.41 \%$ and $0.49 \%$ and $0.52 \%$ in green pepper (Rumi), peas and squash in Qalubia and Fayoum Governorates, respectively during February. Meanwhile during March the rat damage percentages which caused by Arvicanthis niloticus (Desmart), in the same vegetables mentioned previously were $0.42 \%$ and $0.48 \%, 0.53 \%$ and $0.56 \%$ and $0.61 \%$ and $0.67 \%$ for each of Qalubia and Fayoum Governorates, respectively. The represented data in Tables one and two cleared that the rat damage varied considerably according to the location of the field and from month to another. Fayoum Governorate showed the highest percentages of rat damage in the whole investigated vegetables in February in tomatoes $0.66 \%$ followed by squash $0.52 \%$, peas $0.41 \%$ and green pepper (Rumi) $0.37 \%$, whereas Qalubia trials showed the lowest damage in the same vegetable during February. The gained figures proved that the highest rat damage percentages were recorded during March in the whole investigated vegetables for both Governorates. Regarding the population density of Arvicanthis niloticus (Desmart) and there active burrows in the for vegetable crops it was found that tomatoes crop showed the highest percentages of population $(0.4 \%$ and $0.4 \%$ and the number of the active burrows 4.1 and 4.9 in February and $0.7 \%$ and $0.8 \%$ and 4.6 and 5.7 in March for Qalubia and Fayoum Governorates respectively. whereas, green pepper (Rumi) field showed the lowest percentages of population $0.1 \%$ and $0.3 \%$ and the number of the ac- tive burrows 1.7 and 1.9 in February and $0.2 \%$ and $0.4 \%$ and 2.1 and 2.5 in March for Qalubia and Fayoum Governorates respectively. In general, the former results proved that the Field Nile Rat damage percentages, population density and number of the active burrows in the field of the experimented vegetables differs from crop to crop, from location (Governorate) to location and from month to month during the repine stage. Also, the result obtained proved that there is a positive correlation between the rat damage percentages and each of population density of rat and there active burrows in the field. Tomatoes crop had the highest damage, population density and numbers of active burrows. The same conclusion was recorded for Fayoum Governorate. Than Qalubia Governorate during March. Mean while green pepper (Rumi) crop had the lowest damage, population density and numbers of active burrows in Qalubia Governorate during February. Abd ElGawad and Ali (1982) found that maize was the most attractive bait for rodents in upper Egypt. El-Deeb et al., (1985a) found that the wheat was the most preferred bait to Arvicanthis niloticus (Desmart) when compared with maize, sorghum, rice, bagasse, soy bean and cake of cotton seed. ElDeeb et al.,(1985b) found that tomatoes suffered the highest damage $4.73 \%$ followed by strawberry $2.48 \%$, squash $1.41 \%$ and peas $0.43 \%$ in some Delta Governorates in Egypt. Asran et al., (1985) showed that the stored food stuffs found in Arvicanthis niloticus (Desmart) burrows were kernels of wheat, rice, maize and horse bean as well as clover and 
herbs. Abd El-Kader et al.,(2014) stated that rice grains were the most preferred and consumed by both males and females of Rattus norvegicus (Berkanhout), followed by wheat, clover and maize seeds. Asran et al., (2015) reported that for rodent damage to winter crops, the rodents attacked tomatoes lower than wheat; mean while, rat damage for horse bean was less than each of wheat and tomatoes. The summer crops they could be arranged in descending order according to their mean of damage percentages were: maize $0.57 \%>$ tomatoes $0.55 \%>$ soybean $0.23 \%$.

\section{References}

Abd El-Gawad, K. H. and Ali, A. Maher (1982). The active burrowsas a parameter for the detection of population density of rodents during rat control campaigns. Assiut J. Agric. Sci., 13 (2): 115-120.

Abd El Kader, M. R.; A. A. Asran; A. A. R. Al Gandy and K.E. Khalel (2014).Food preference for Albino rats and Albino mice under laboratory conditions. Egypt J. Agric., Res., (92), (4): 1279 -128.

Asran, A.A.; El Deeb, H.I.; Kuehnert, G. and El-Halfawy, M.A. (1985). Population density of rodents in different locations in Fayoum Governorate. J. Agric., Sci., Mansoura Univ., Egypt. 10 (4): 15271528.

El Deeb, H.I.; A.A. Asran; G. Kuehnert and M.A.El-Halfawy (1985a). Bait preference and bait consumption of the Nile rat, Arvicanthis niloticus. Zagazig Journal Agaric, Res., 12,
(1): 45-49.

El Deeb, H. I.; A.A. Asran; G. Kuehnert and M. A. El-Halfawy (1985b). Rodent damage to Strawberry, Squash, Tomatoes and Peas in some Delta Governoratesin Egypt. J. Agric., Sci., Mansoura Univ., 10 (4):1515-1516.

Jackson, W.B. (1974). A Study of Rodent Damage to Food in some $\mathrm{Cu}-$ ban Warehouse and Coast of Preventingit. J. of Stared Products Research. 20, (20): $83-86$.

Lal, S. S. and Pillai, K. S. (1981). Rodent Pests of Paid and Oil Palms in West Malaysia, Asia and Pacific Region US FAO, UN. Nemea, New Caledonia, 15 -23 July 1981.

Meehan, A.P. (1984). Rats and mice their biology and control. Published by Rentokil Limited East Grain Stead. W. Sussex RH. 192 J.Y. London U.K.

Parkin, E.A.(1959). Insects and Stored Food. World Losses and Control Measures Surveyed Food. Manuel. 34, 164-168.

Wahab, A.E.; A.A. Asran and T.M. Keshat (1997). Survey and damage appraisal of Egyptian rodents in certain field crops in the some Governorates. Al-Azhar J. Agric. Res., 25 (1): 261-268.

Winygaarden, A. Van. (1957). Rodent Damage to Growing Crops and to Farm and Realize Storage in Tropical and Sub Tropical Regions. Center of Creases Pest Research Tropical Products Institute.

Werneck, (1973). Food Habits of Rodents in a Cultivated Ecosystem. J Mammal, 59, (2): 427 - 430. 
Website: www.aun.edu.eg/faculty_agriculture/journals_issues_form.php_E-mail: ajas@aun.edu.eg

الضرر الذي يحدثه جرذ الحقل النيلي Arvicanthis niloticus (Desmart) لبعض محاصيل

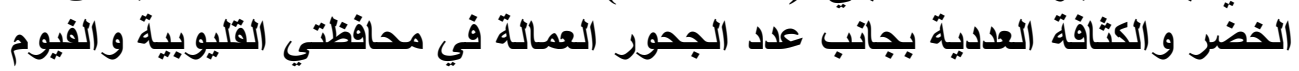
عبد الموجود عبد الله عسران و ياسر محمد عبد القوي عبد الجليل

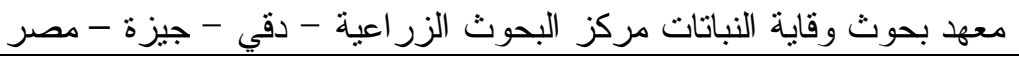

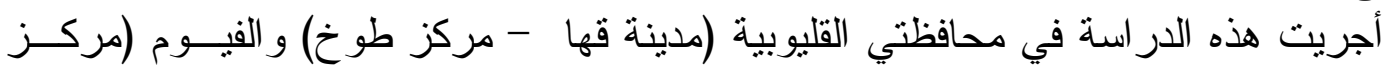

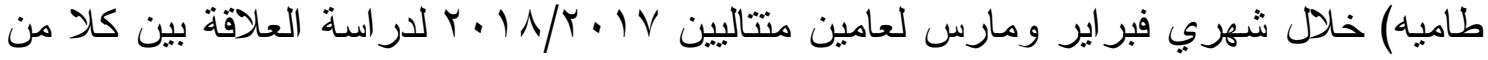
الكثافة العددية لجرذ الحقل النيلي (Desmart)

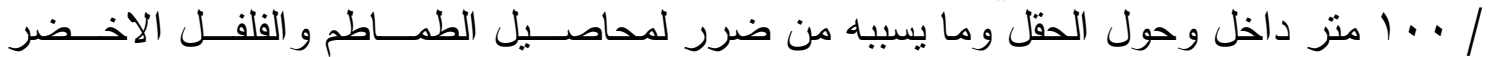

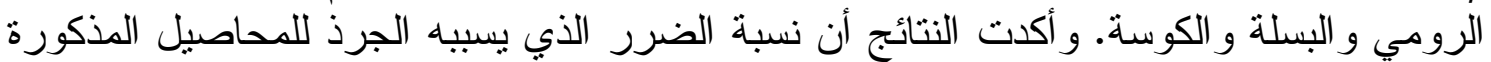

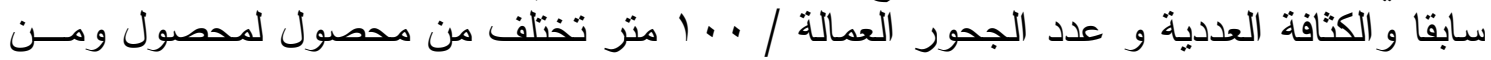

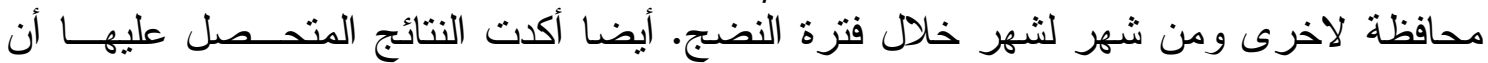

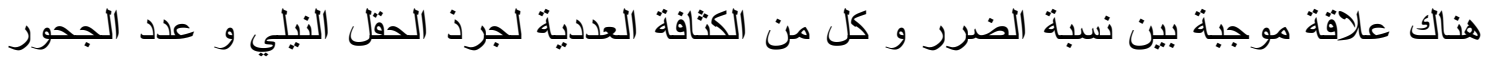

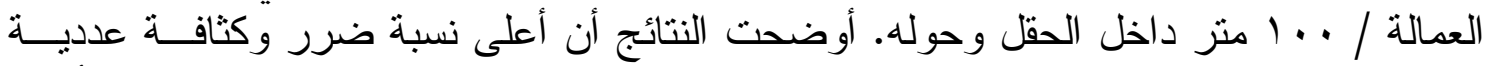

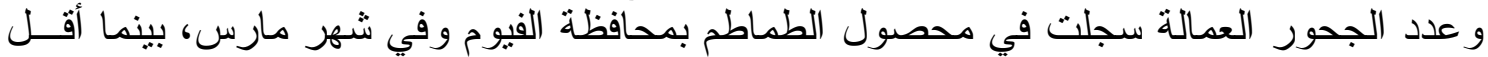

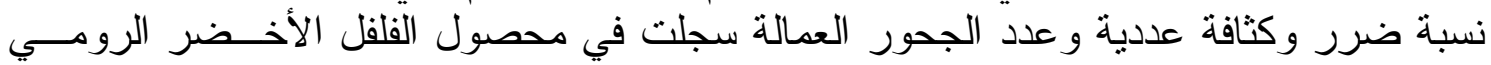
بمحافظة القليوبية وفي شهر فبر اير ماند 
Table 1. Population density and active burrows Arvicanthis niloticus, (Desmart) and its damage to certain vegetables in Qalubia Governorate during two successive years 2017 and 2018.

\begin{tabular}{|c|c|c|c|c|c|c|c|c|c|c|}
\hline \multirow{3}{*}{ Crop } & \multirow{2}{*}{\multicolumn{2}{|c|}{$\begin{array}{c}\text { Population } \\
\text { density of } \\
\text { Arvicanthis } \\
\text { niloticus/100 m. }\end{array}$}} & \multirow{2}{*}{\multicolumn{2}{|c|}{$\begin{array}{c}\text { Average of } \\
\text { active } \\
\text { burrows } / 100 \mathrm{~m} .\end{array}$}} & \multicolumn{6}{|c|}{ Damage\% } \\
\hline & & & & & \multicolumn{3}{|c|}{ Feb. } & \multicolumn{3}{|c|}{ March } \\
\hline & Feb. & March & Feb. & March & Mean \pm S.E & Min & Max & Mean S.E & Min & $\operatorname{Max}$ \\
\hline Tomato & 0.4 & 0.7 & 4.1 & 4.6 & $0.58 \pm 0.07$ & 0.32 & 0.69 & $0.69 \pm 0.16$ & 0.44 & 1.21 \\
\hline $\begin{array}{l}\text { Green } \\
\text { pepper } \\
\text { (Rumi) }\end{array}$ & 0.1 & 0.2 & 1.7 & 2.1 & $0.33 \pm 0.04$ & 0.24 & 0.48 & $0.42 \pm 0.04$ & 0.33 & 0.53 \\
\hline Peas & 0.3 & 0.6 & 3.2 & 3.6 & $0.41 \pm 0.08$ & 0.23 & 0.61 & $0.53 \pm 0.07$ & 0.41 & 0.68 \\
\hline Squash & 0.3 & 0.4 & 3.6 & 3.8 & $0.49 \pm 0.05$ & 0.39 & 0.58 & $0.61 \pm 0.07$ & 0.49 & 0.75 \\
\hline
\end{tabular}

Table 2. Population density and active burrows Arvicanthis niloticus, (Desmart) and its damage to certain vegetables in Fayoum Governorate during two successive years 2017 and 2018.

\begin{tabular}{|c|c|c|c|c|c|c|c|c|c|c|}
\hline \multirow{3}{*}{ Crop } & \multirow{2}{*}{\multicolumn{2}{|c|}{$\begin{array}{l}\text { Population den- } \\
\text { sity of } \\
\text { Arvicanthis } \\
\text { niloticus / } 100 \text { m. }\end{array}$}} & \multirow{2}{*}{\multicolumn{2}{|c|}{$\begin{array}{l}\text { Average of } \\
\text { active } \\
\text { burrows/100 m. }\end{array}$}} & \multicolumn{6}{|c|}{ Damage\% } \\
\hline & & & & & \multicolumn{3}{|c|}{ Feb. } & \multicolumn{3}{|c|}{ March } \\
\hline & Feb. & March & Feb. & March & Mean \pm S.E & Min & $\operatorname{Max}$ & Mean S.E & Min & Max \\
\hline Tomato & 0.4 & 0.8 & 4.9 & 5.7 & $0.66 \pm 0.09$ & 0.50 & 0.81 & $0.78 \pm 0.11$ & 0.58 & 0.96 \\
\hline $\begin{array}{l}\text { Green } \\
\text { pepper } \\
\text { (Rumi) }\end{array}$ & 0.3 & 04 & 1.9 & 2.5 & $0.37 \pm 0.04$ & 0.29 & 0.52 & $0.48 \pm 0.08$ & 0.30 & 0.67 \\
\hline Peas & 0.3 & 0.7 & 3.3 & 3.6 & $0.41 \pm 0.06$ & 0.26 & 0.58 & $0.56 \pm 0.02$ & 0.45 & 0.66 \\
\hline Squash & 0.4 & 0.6 & 4.1 & 4.8 & $0.52 \pm 0.04$ & 0.44 & 0.61 & $0.67 \pm 0.09$ & 0.51 & 0.83 \\
\hline
\end{tabular}

